\title{
Application of Learning Strategies Contextual Teaching and Learning (CTL) in Improving Student Learning Outcomes in Ancient and Modern Human Materials
}

\begin{abstract}
Suwarno
SMAN 1, Kota Mojokerto

Email: suwarno.031966@gmail.com

\section{ABSTRACT}

The purpose of this classroom action research is to know the students' learning mastery. This study is limited to the subjects of history. The subjects of the study were students of Class X IPS-1 SMA Negeri 1, Kota Mojokerto semester of the academic year 2017/2018 which amounted to 36 students. This research is a class action research (action research). The learning tools used in this study include syllabus and lesson plans. The research instrument consists of observation / observation sheet of student and teacher activity and student response questionnaire. The result of the research shows that learning with Contextual Teaching Learning (CTL) strategies is quite effective which is marked by the increase of the percentage of students' learning result completion by classical from $70.56 \%$ (round 1), $75.53 \%$ (round 2) and $86.67 \%$ (round 3 ).
\end{abstract}

Keywords: CTL, Contextual teaching learning, History, Learning result

\section{INTRODUCTION}

History has a strategic meaning in shaping the character and civilization of a nation with dignity and shaping Indonesian people who have a sense of nationality and love for the country. History is a subject that focuses on the formation of citizens who understand and are able to exercise their rights and obligations to become smart, skilled, and characterized Indonesian citizens mandated by the Pancasila and the 1945 Constitution.

Early and Modern Human Material is one of the materials discussed in the field of History study at SMA / MA in K-13 with basic competencies, namely ancient and modern humans, ancient Indonesian humans, world ancient humans and modern humans. In this subject matter, many of the concepts are obtained from observations and facts that are presented in everyday life. A learning concept that helps teachers link the material being taught with real-world situations and encourages students to make connections between their knowledge and its application in life, thus further empowering students and encouraging students to construct knowledge in their own minds, namely through the CTL (Contextual Teaching Learning) strategy.

The learning that will be applied to this ancient and modern human subject will use the CTL learning strategy. Learning activities and understanding processes in accordance with the principles of constructivism and inquiry. By providing examples of questions and ways to solve them, a teacher has fulfilled the modeling principle, besides that, it is continued by giving questions to students in groups according to the principles of the learning community. There is one group presenting their writing, encouraging other students to ask questions and express opinions. This is in accordance with the principle of asking. Before the lesson is closed, students are asked to summarize the material that has been studied in the reflection process. To measure students 
understanding of ancient and modern human material, it was implemented using the Contextual Teaching Learning (CTL) strategy.

CTL is a learning concept that helps teachers link the material taught with realworld situations and encourages students to make connections between their knowledge and its application in their lives as family members and society. Contextual Teaching Learning (CTL) has seven main components in effective learning, namely constructivism, questioning, inquiry, learning community, modeling, reflection and authentic assessment.

\section{RESEARCH METHODS}

This research was conducted using classroom action research (CAR). Classroom action research (CAR) is a type of research that is able to offer a new procedural approach that promises a direct impact in the form of improvement and enhancement of teacher professionalism in managing the teaching process in the classroom. This CAR is carried out in the form of a cyclic learning process. This classroom action research consisted of three rounds of teaching and learning activities. Each round consists of 4 stages, namely: research planning / planning, action / observation, reflection, and revision.

The purpose of this study was to determine the implementation of Contextual Teaching Learning (CTL), teacher activities, student activities and learning outcomes while using Contextual Teaching Learning (CTL) strategies, on the subject matter of ancient and modern humans. The target of this research is student learning outcomes with Contextual Teaching Learning (CTL) strategies on the subject matter of ancient and modern humans in class X IPS (Social Science) 1 semester 2, SMA Negeri 1, Mojokerto, totaling 36 students.

The research instruments used in this study were observation sheets, learning outcome test sheets, and student response questionnaires. Methods of data collection using observation methods, test methods, and questionnaire methods. Analysis to determine each student's learning completeness. Individually, students complete their learning if they reach absorption capacity of $70 \%$ and above or a grade of $>75$. While classically a class has finished learning if $85 \%$ of students have reached absorption capacity of $65 \%$ and above.

\section{FINDING AND DISCUSSION}

\section{First Round}

Judging from the percentage of time in teaching and learning activities, the percentage of time used by students to actively learn in class was $77.40 \%$ in the good category, with the details of reading textbooks (14.07\%), expressing opinions (4.81\%), asking questions between students (7.41\%), asking between students and teachers (7.78\%), concluding the material that has been studied $(1.85 \%)$, analyzing and presenting written works $(11.85 \%)$, communicating / presenting papers in groups $(11.11 \%)$ and doing assignments and tests from the teacher (18.52\%). On the other 
hand, teacher activity in round 1 received a sufficient category with a percentage of $41.49 \%$ used to motivate students $(1.48 \%)$, link new experiences with initial knowledge (5.19\%), provide guided training (14.44\%), check understanding and provide feedback $(15.19 \%)$ and discussed with students $(4.08 \%)$. This is due to the lack of teacher skills in helping students to be active in teaching and learning activities. In round 1 the learning provided was only in the form of material delivery from the teacher with a percentage of activity of $15.92 \%$. During the provision of this material, students tended to listen $(15.19 \%)$ and read textbooks $(14.07 \%)$, this was because students were not familiar with teaching and learning activities using Contextual Teaching Learning (CTL) strategies in ancient and modern human material and did not seem to be in accordance with the theory. constructivists that teaching and learning activities should be student centered, not teacher centered.

In addition, there was also giving examples from teachers $(22.59 \%)$ and giving exercises $(20.74 \%)$ to hone students' skills in solving a question both individually and in groups. The formation of study groups was carried out randomly by students with guidance from the teacher $(10.37 \%)$. The existence of learning groups in teaching and learning activities in accordance with the learning community components in the Contextual Teaching Learning (CTL) strategy with a good category. Group learning and examples carried out by the teacher lead to good interaction between the teacher and students and between students themselves in the classroom during teaching and learning activities. When the teacher links new experiences with students' initial knowledge with a percentage of $5.19 \%$, the teacher provides guided exercises with a percentage of $20.74 \%$, the teacher exemplifies how to make good and correct writing with a percentage of $22.59 \%$ and the teacher checks understanding and provides feedback with a percentage of $15.19 \%$, then there can be interactions between teachers and students, namely by discussing with students with a percentage of $4.08 \%$. While the interaction between students can be seen with the activity of asking questions between students with a percentage of $7.41 \%$, analyzing and presenting papers with a percentage of $11.11 \%$, doing assignments from the teacher with a percentage of $18.52 \%$.

At the end of learning, students are invited to conclude the material that can be seen from the teacher's activities with a percentage of $1.86 \%$ and student activity of $1.85 \%$, which is in line with the low implementation of Contextual Teaching Learning (CTL) in the reflection component in concluding the material that has been studied with assessment 3 or getting a moderate category.

\section{Second Round}

Judging from the percentage of time in teaching and learning activities in second round, it shows that the percentage of time used by students to be active gets a percentage of $90.11 \%$ with a very good category, with details of reading textbooks (17.28\%), expressing opinions (7.65\%), analyzing and presenting written works $(3.70 \%)$, asking between students $(8.89 \%)$, asking between students and teachers $(7.16 \%)$, concluding the material that has been studied $(5.68 \%)$, conducting research 
activities (13.58\%), analyzing and presenting written works (3.70\%), communicating / presenting papers in groups $(3.70 \%)$ and doing assignments and tests from the teacher $(22.22 \%)$. Only $10.12 \%$ of the time is used by students to listen to teacher explanations and irrelevant behaviors. Thus the teaching and learning activities in round 2 are in accordance with the constructivist theory that teaching and learning activities are centered on students (student centered) and not on teachers (teacher centered).

On the other hand, teacher activity in second round got a percentage of $73.08 \%$ with a good category used to motivate students (3.21\%), linking new experiences with initial knowledge (1.97\%), providing guided training (19.51\%), checking understanding and providing feedback (27.90\%) and discuss with students (18.52\%).

If the data obtained is compared with the data in first round, it turns out that the time used by students to carry out activities has increased, from $77.40 \%$ (round 1) to 90.11\% (round 2). The increased student activity included reading textbooks (from $14.07 \%$ to $17.28 \%$ ), expressing opinions (from $4.81 \%$ to $7.65 \%$ ), asking questions between students (from $7.41 \%$ to $8.89 \%$ ), concluding the material that had been studied (from $1.85 \%$ ) to $5.68 \%$ ), conducting research activities (from none to $13.83 \%$ ) and shouting assignments and tests from teachers (from $18.52 \%$ to $22.22 \%$ ). Whereas in quru activity there was an increase from (round 1) to $73.08 \%$ (round 2). Teacher activities that have increased include motivating students (from $1.48 \%$ to $3.21 \%$ ), providing guided training (from $14.44 \%$ to $19.51 \%$ ), checking understanding and providing feedback (from $15.19 \%$ to $27.90 \%$ ) and discussing with students. (from $4.08 \%$ to $18.52 \%)$. This increase is due to

In second round, the material is a lot of calculations that involve a lot of interaction between the teacher and students, many practice questions are held and research activities are held and there are no examples from the teacher. In second round the average score of students in the class was 76.12 with 28 students who completed their studies, so that there were still 8 students who did not complete their studies. From the number of students who completed the study, $75.56 \%$ classical completeness was obtained and it could not be said to be complete because it was still below the teaching and learning activities set by the school. When compared in first round $(82.22 \%)$, classical learning completeness was reduced, because in second round, the material was mostly in the form of counted questions and was supported by student response questionnaires which stated difficulties while doing the tests given by the teacher $(28.89 \%)$.

In addition, students' interest in the implementation of the Contextual Teaching Learning (CTL) strategy increased, this was shown by the student response, from $88.89 \%$ in round 1 to $93.33 \%$ in round 2 who wanted the same thing for the next teaching and learning activities and from $84.44 \%$ in round 1 to $100 \%$ in round 2, the students agreed that other subject matter was taught using the Contextual Teaching Learning (CTL) strategy. 


\section{Third Round}

Judging from the percentage of time in the teaching and learning activities in round 3 , the percentage of time used by students to be active got a percentage of $87.03 \%$ with a very good category, with details of reading textbooks (11.48\%), expressing opinions $(11.85 \%)$, asking questions between students $(8.15 \%)$, ask questions between students and teachers (5.56\%), summarize the material that has been studied $(5.93 \%)$, carry out research activities (5.55\%), analyze and present papers (11.11\%), communicate / present written works in groups (5.55\%) and doing assignments and tests from the teacher $(21.85 \%)$. Only $18.15 \%$ of the time was used by students to listen to teacher explanations and irrelevant behaviors. Thus, the teaching and learning activities in round 3 are in accordance with the constructivist theory that teaching and learning activities are centered on students (student centered) and not on teachers (teacher centered).

On the other hand, teacher activity in round 3 got a percentage of $69.26 \%$ with a good category used to motivate students (3.33\%), linking new experiences with initial knowledge (11.11\%), providing guided training (16.30\%), checking understanding and providing feedback $(22.22 \%)$ and discussing with students (16.30\%). If the data obtained is compared with the data in round 2 , it turns out that the time used by students to carry out activities has decreased, from $90.11 \%$ (round 2) to $69.26 \%$ (round 3), because the teaching and learning activities in round 3 are mostly in the form of material only.

The declining student activities include asking questions between students (from $8.89 \%$ to $8.15 \%$ ) and asking questions between students and teachers (from $7.16 \%$ to $5.56 \%$ ) because students have started to get used to discussion activities so that the discussion goes fast and smoothly which is supported by the results of the Contextual Teaching Learning (CTL) implementation data on the asking component in the aspect of asking questions during discussion and the aspect of respecting other people's opinions (from 4 with good categories to 4.33 with good categories), conducting research activities (from $13.83 \%$ to $5.55 \%$ ) and doing assignments and tests from teachers (from $22.22 \%$ to $21.85 \%$ ) because students have been able to work together well in their groups and are aware of the assignments of each student in their group and at the time of taking the test from the teacher the students stated that they did not have difficulty doing it, this is reinforced by the result data student response questionnaires with a percentage of $100 \%$ and the results of the Contextual Teaching Learning (CTL) implementation data on Inquiry component in the aspect of observing / observing (from 4 with good categories to 4.33 with good categories), modeling components in the aspect of doing assignments from the teacher (from 4 with good categories to 4.33 with good categories), components of the learning community in the aspect of discussing to do practice questions (from 4.67 with good categories to 5 with very good categories), the question component in the aspect of presenting group papers in front of the class (from 3.67 with the medium category to 4 with the good category), the constructivism component in the aspect of conducting research activities (from 4 with good categories 
to 4 with good categories), authentic assessment components in the aspect of student skills during the study (from 5 with very good categories to 5 with very good categories) and aspects of doing individual test questions (from 4.67 with good categories to 5 with very good categories) well).

In third round, the average grade of students in the class was 88.44 with 39 students who completed their studies, so there were still 6 students who did not complete their studies. From the number of students who completed their studies, $70.56 \%$ classical completeness was obtained and it was said to be complete because it was above the SKBM set by the school. When compared to round $2(75.56 \%)$, classical learning completeness increased.

In addition, students' interest in learning with Contextual Teaching Learning (CTL) strategies remains large, this is shown by the student response, namely $93.33 \%$ or as many as 32 students who want the same thing for the next teaching and learning activity and $100 \%$ or 36 students agree that other subject matter taught with Contextual Teaching Learning (CTL) strategies. And during the lesson $100 \%$ or 36 students were happy.

\section{CONCLUSIONS}

Teaching with the Contextual Teaching Learning (CTL) strategy was quite effective, which was marked by an increase in the percentage of student learning outcomes classically starting from $70.56 \%$ (round 1), $75.53 \%$ (round 2) and $86.67 \%$ (round 3). Learning with the Contextual Teaching Learning (CTL) strategy can activate students in learning ancient and modern human materials. Learning activities have been student-centered, which is characterized by interactions between students in conducting investigations, analyzing papers and communicating written papers as well as studentteacher interactions in terms of expressing ideas, asking and answering questions from the teacher.

Learning activities with Contextual Teaching Learning (CTL) strategies that have been carried out by researchers can activate students in learning and get a positive response from students, so it is advisable to develop the same learning tools for other subject matter and need to be followed up to be applied to other subject matter or other subjects. so that students get used to it.

\section{REFERENCES}

Azizah, Utiya. 2003. Pendekatan Kontekstual (Contextual Teaching And Learning (CTL)). Makalah disampaikan dalam kegiatan uji coba naskah model buku pelajaran PPKN, Geografi, Biologi, dan Kimia.

Depdiknas. 2003. Pedoman Pembelajaran Tuntas (Mastery Learning). Jakarta: Direktorat Jenderal Pendidikan Dasar dan Menengah

Mulyasa, E. 2003. Kurikulum Berbasis Kompetensi, Konsep, Karakteristik, Implementasi, dan Inovasi. Bandung: PT Remaja Rosdakarya

Mursell, J. S, Nasution.1995. Mengajar Dengan Sukses. Jakarta : Bumi Aksara 
Riduwan. 2003. Skala Pengukuran Variabel-Variabel Penelitian. Bandung: alfa beta Sanjaya, Wina. 2003. Pembelajaran dalam Implementasi Kurikulum Berbasis Kompetensi. Edisi pertama. Bandung: Prenada Media Grup

Suryosubroto. 1997. Proses Belajar Mengajar di Sekolah. Jakarta: Rineka Cipta 